\title{
The Effect of Governance and Sharia Compliance Implementation Towards the Level of Customer Trust in Islamic Banks
}

\author{
Muhamad Dede Sulaeman¹, Sigid Eko Pramono², Saiful Anwar³
}

\begin{abstract}
This research aims to find out how much the effect of the governance and sharia compliance implementation towards the level of customer trust in Islamic bank in Bogor. There were 159 customers of Islamic banks selected as sample. The analytical method used in this research is Structural Equation Modeling (SEM). The results presented that governance does not significantly affect the level of Islamic bank's customer trust, while conversely sharia compliance has a significant positive effect on the level of Islamic bank's customer trust. Thus, to increase customer trust in Islamic banks, it is necessary to improve sharia compliance.
\end{abstract}

Keywords: Governance, Sharia Compliance, Consumer Trust, Islamic bank

\begin{abstract}
Abstrak. Penelitian ini bertujuan untuk mengetahui seberapa besar pengaruh penerapan tata kelola dan kepatuhan syariah terhadap tingkat kepercayaan nasabah pada bank Syariah. Jumlah sampel 159 nasabah bank syariah. Metode analisis yang digunakan dalam penelitian ini adalah Structural Equation Modeling (SEM). Hasil yang diperoleh adalah variabel tata kelola tidak berpengaruh terhadap tingkat kepercayaan nasabah bank syariah di Bogor, sedangkan sebaliknya kepatuhan syariah berpengaruh positif secara signifikan terhadap tingkat kepercayaan nasabah bank syariah. Oleh karena itu, untuk meningkatkan kepercayaan nasabah pada bank syariah di Bogor, perlu dilakukan perbaikan tata kelola bank syariah dengan tetap mengutamakan peningkatan kepatuhan syariah.
\end{abstract}

Kata kunci: Tata Kelola, Kepatuhan Syariah, Kepercayaan Nasabah, bank syariah

${ }^{1}$ Department of Islamic Accounting, Tazkia Islamic University College| mdedesulaeman@gmail.com

${ }^{2}$ Department of Islamic Accounting, Tazkia Islamic University College| sigideko@tazkia.ac.id

${ }^{3}$ Department of Islamic Accounting, Tazkia Islamic University College| olieanwar@gmail.com 


\section{Introduction}

One of the fundamental aspects that distinguish sharia and conventional financial industry is the matter of compliance with sharia compliance principles (Noman, 2003). Thus, the application of sharia governance principles implemented by Islamic banking may affect the market share of Islamic banking. In a study, about $85 \%$ of customers will move to another bank due to failure in implementing sharia principles (Ahmed and Chapra, 2002). Therefore, good corporate governance (GCG) and the application of the principles of sharia (sharia governance) becomes a necessity in order to improve the image and reputation of Islamic banking, as well as protecting the interests of stakeholders in an effort to give confidence and health in the Islamic banking system, which has been a demand since the 21st century. Based on Bank Indonesia Regulation No. 11/33/PBI/2009, Banks are obliged to carry out GCG in each of its business activities at all levels of the organization.

The purpose of this research is to obtain data and information on governance and sharia compliance in Islamic banks and to determine the extent of its role in customer confidence levels.

\section{Literature Review}

Good Corporate Governance is a system that regulates and controls the company to create value added for all stakeholders (Khairandy \& Malik, 2007). The concept of governance/GCG in Indonesia can be interpreted as the concept of good corporate management. Two things emphasized in the GCG concept. First, the importance of the right of shareholders to obtain information correctly (accurately) and in time Second, the obligation of the company to make disclosure (disclosure)transparently, accurately and timely against all company performance information, ownership, and stakeholders.

There are five GCG principles contained in law No.40 of 2007, namely Transparency/Disclosure, Accountability, Responsibility, Independency/ SelfReliance, and Fairness. 
The Governance/GCG in Islam is different and unique to the concept of GCG in the perspective of the western world. The term of GCG is very closely related to one of the hadith of the Messenger of Allah (peace and blessings of Allah be upon him) which was narrated by Aisha Radiallahu'anha which means "God likes if one does a good job" (HR. Thabrani). The principles of Good Corporate Governance have been highlighted for 14 centuries ago. Thus, Indonesia, a country that is predominantly Muslim, is required to know and understand implementing the principles of GCG in the context of Islam and that is nothing new. But in the form of Islamic management, along with the development of the principles of western capitalism, the principles of Islam were then abandoned by Muslims.

Some similar research have been conducted previously. For instance, Rumadan, Askandar, \& Amin (2018) found that responsibility, independence, justice and Sharia Compliance affect customer loyalty, while transparency has no significant effect on customer loyalty. Another research by Janusi (2012) concluded that the calculation of the total assessment of sharia governance implementation in Islamic banks (Muamalat bank) shows an average score of 3.427 with good category. This shows that sharia compliance is the indicator that contributes the most in the implementation of sharia governance. Adherence to sharia is the main factor of customers in establishing partnerships with Islamic banks and deciding to keep Islamic banks.

Meanwhile, Wardayati (2011) argued that he implementation of sharia governance includes six indicators namely transparency, accountability, responsibility, independence, fairness, and sharia compliance has shown good results. Sharia compliance is the dominant Islamic government indicator, while accountability and fairness are weak indicators for explaining sharia governance. The implementation of sharia governance has a significant influence on the reputation and trust of customers in Islamic banking. This result is also supported by Yuraida (2016) that Sharia compliance is the dominant Islamic government indicator that significantly affect the reputation and trust of customers in Islamic banking. 


\section{Methods}

The data used in this study are primary data and secondary data. This research is also intended to test hypotheses that have been formulated previously. At the end of the chapter the results of this study explain the causal relationship between variables through hypothesis testing. As for the purpose of this study to determine the relationship of three variables, namely the Implementation of Governance (X1), Sharia Compliance (X2) which is an exogenous variable and customer trust $(\mathrm{Y})$ as an endogenous variable.

Before processing the data, the questionnaire was tested for validity and reliability. Then, continued with data analysis. This research employed descriptive analysis method and Structural Equation Modeling (SEM) with the SmartPLS 3 application. The sample in this study were customers of Bank Syariah Mandiri and BNI Syariah in Bogor with a sample size of 159 respondents using simple random sampling technique so that each population can be used as a research sample and have the same opportunity.

The dependent variable consists of trust, while the independent variables are shariah compliance and Islamic bank Governance / GCG. In this study the variable measurement scale refers to the Likert scale, which is to measure the attitude of the research object through a statement of agreement (Hermawan, 2005) where each question is given five answer categories, namely: (1) $\mathrm{SS}=$ Strongly Agree, (2) $\mathrm{S}=$ Agree, (3) $\mathrm{N}=$ Neutral, (4) TS = Disagree, and (5) STS = Strongly Disagree. This study will examine the effect of governance implementation on customer trust in BSM and BNIS in Bogor. Processing and analysis techniques are the most decisive steps in a study, because data analysis serves to conclude the research results. The data were collected by distributing questionnaires as a research instrument, using a Likert scale of 1-5. The analysis techniques used are: first, to determine the implementation of governance using quantitative descriptive analysis. second, to test the effect of governance implementation on customer trust in Islamic banks in Bogor using the method Structural Equation Modeling (SEM) with the help of software SmartPLS 3. 


\section{Results and Discussion}

As an illustration of the customer profiles of Islamic banks in Bogor who are respondents to this study, it can be stated that in the questionnaire, the gender categories were divided into two, namely men and women. Of the results identified that slightly more respondents were men as many as 68 people or $43 \%$ were women by 91 people or $57 \%$. So, it can be assumed that the management of family finances is mostly done by women.

Second, the age profile of respondents are dominated by the age between 20-29 years with the number of respondents as 59 people or equivalent to $37 \%$, while the second largest rank between $30-39$ years old is 58 people or $36 \%$ and followed by the age between $40-49$ years old as 33 people or equivalent $21 \%$ and the age of more than 50 years is only 8 people or $5 \%$, but there is one person who does not answer. So, it can be assumed that the ages of 20-39 are young and established age who are indeed productive times and begin to prepare financially.

Third is the profile of respondents' jobs. From the results of the questionnaire, it was found that 90 respondents were Private Employees or equivalent to $42.06 \%$, followed by respondents with other jobs of 33 people or $15.42 \%$, Students as many as 31 people or $14.49 \%$, Housewives as many as 27 people or $12.62 \%$, then self-employed as many as 21 people or $9.81 \%$ and lastly civil servants / TNI / POLRI with the number of respondents as many as 12 people or $5.61 \%$. It can be assumed that most respondents are private employees who have a fixed income, so that in financial management can easily manage finances.

Fourth is the profile of the length of time the respondent has been a customer of an Islamic bank. The length of time the respondent has been a customer of an Islamic bank is one of the questions contained in the questionnaire addressed to the respondent and is divided into three groups, namely the group 1 year $<5$ years, $5<10$ years and more than 10 years as a bank customer sharia. From the results of distributing questionnaires, it was found 
that the 1 year $<5$ years group was $52 \%$, the $5<10$ years group was $24 \%$, the group more than 10 years was $21 \%$ and the group who was less than 1 year old or did not fill in was 3\%. The distribution of respondents based on the length of time they have been customers shows that more than half of the respondents 1 year to less than 5 years have become customers of Islamic banks, so it can be assumed that Islamic banks only started operating in 1991.

Fifth is the profile of respondents' education level. In distributing the questionnaire, it can be seen that half of all respondents were 82 undergraduate (S1) graduates or about $52 \%$, followed by 40 SMA / Aliyah graduates or about $25 \%$, while 16 Diploma/D3 graduates or about $10 \%, 11$ people S2 graduates or about $7 \%$, followed by 5 S3 graduates or about $3 \%$ and 3 people or about $2 \%$ are SMP / MTS graduates, the remaining 2 people or the equivalent of $1 \%$ under SD / Not attending school. It can be assumed that more than half of the respondents are S1 graduates so that awareness in terms of financial planning is higher than other levels of education.

In conducting SEM analysis there are three kinds of activities simultaneously, namely checking validity tests and instrument reliability tests, testing models the relationship between variables and activities to get a model suitable for prediction (related to regression analysis or structural model analysis) (Sugiyono, 2013). A questionnaire is declared valid when the questions on the questionnaire are able to reveal something that will be measured by the questionnaire. The level of validity can be measured by comparing the value of $r$ count (correlation item total correlation) with $r$ table with the provisions of degree of freedom $(\mathrm{df})=\mathrm{n}-2$, where $\mathrm{n}$ is the number of samples. The validity test is used to measure whether a questionnaire is valid or not. The validity test is done by comparing the calculated $r$ value with the $r$ table for the degree of freedom (df) $n=n-2, n$ is the number of samples. In this study, the sample size was 159 respondents and the amount of $\mathrm{df}=$ can be calculated as $159-2=157$ with $\mathrm{df}=157$ and alpha $=0.05$ obtained $\mathrm{r}$-table $=0.159$ means that if the calculated $r$ is obtained $>\mathrm{r}$-table (0.159) it can be concluded that all questionnaire questions are valid. From the results of the questionnaire 
validity test, it can be seen that all question indicators have a value of $r$-count $>$ 0.159 , which means that all items of the questionnaire questions can be said to be valid.

Table 4. Value of Cronbach's Alpha, Composite Reliability and Average Variance Extracted (AVE)

\begin{tabular}{lccc}
\hline & $\begin{array}{c}\text { Cronbach's } \\
\text { Alpha }\end{array}$ & $\begin{array}{c}\text { Composite } \\
\text { Reliability }\end{array}$ & $\begin{array}{c}\text { Average Variance } \\
\text { Extracted (AVE) }\end{array}$ \\
\hline Sharia Compliance & 0.954 & 0.962 & 0.783 \\
Customer Trust & 0.942 & 0.953 & 0.743 \\
Sharia Bank & 0.942 & 0.948 & 0.520 \\
Governance & &
\end{tabular}

\section{Source: Processed SmartPLS output}

Based on the results of the reliability test conducted by the author, it is known that the three-variable questionnaire under study scored more than 0.60 , it can be concluded that the research instrument used to measure the research variables is said to be reliable or reliable so that the results of the questionnaire can be continued to the next testing stage.

Testing the hypothesis and the goodness of the model (Goodness of Fit Model) is a way to test the inner model or the relationship between latent variables. Hypothesis Test results can be presented in the table below:

Table 5. Hypothesis Test Results

\begin{tabular}{|c|c|c|c|c|}
\hline & Hypothesis & t-statistic & $\begin{array}{l}\mathrm{t}-\mathrm{table} \\
\text { sig-95\% }\end{array}$ & Results \\
\hline $\mathrm{H} 1$ & $\begin{array}{l}\text { Governance of Islamic banks has a positive, but not } \\
\text { significant, effect on the level of customer confidence } \\
\text { in Islamic banks in Bogor }\end{array}$ & 1,795 & 1,975 & Rejected \\
\hline $\mathrm{H} 2$ & $\begin{array}{l}\text { Sharia compliance has a positive and significant } \\
\text { effect on the level of customer confidence in Islamic } \\
\text { banks in Bogor }\end{array}$ & 3,741 * & 1,975 & Accepted \\
\hline
\end{tabular}

* Significant | Source: SmartPLS output that has been processed

Based on data processing that has been done using the smart PLS 3.0 program, the R-Square value for the Customer Trust variable is 0.659 . This value explains that customer trust can be explained by Sharia Governance and Compliance at $65.9 \%$. Thus, from these results, this research model can be stated as having a good goodness of fit. In addition, all indicators also meet Discriminant Validity. 
In order to determine the relationship between indicators, it is necessary to conduct Multicollinearity Test. To find out whether the formative indicators experience multicollinearity by knowing the VIF (Variance Inflation Factor) value. It can be said that the indicator is multicollinear, namely the VIF value between 5-10. From the following table it can be seen that all the VIF values of the indicator are less than 5, so it can be concluded that there is no indication of multicollinearity. The Outer VIF value for the Multicollinearity Test is the result of the evaluation of the measurement model. It can be stated that all indicators for each variable in measuring the construct are Valid and Reliable.

This research is supported by the results of research by Junusi, (2012) in his research it can be concluded that the total calculation of the assessment of the implementation of sharia governance in Islamic banks (Muamalat bank) shows an average score of 3,427 in a good category. This shows that sharia compliance is an indicator that makes the biggest contribution to the implementation of sharia governance. Adherence to sharia is a major factor for customers in forging partnerships with Islamic banks and deciding to keep their Islamic banks. Furthermore, the results of this study are also supported by the results of research from Yuraida (2016) which stated that the results of data calculations show that the implementation of sharia governance includes six indicators, namely transparency, accountability, responsibility, independence, justice, and sharia compliance, showing varied results. Sharia compliance is a dominant indicator of Islamic government. The implementation of sharia governance has a significant influence on the reputation and trust of customers in Islamic banking.

The AVE value is another convergent validity criterion, it can be seen that the Average Variance Extracted (AVE) value is proven valid because the AVE value of the three constructs is more than 0.5 , namely sharia compliance 0.783, customer trust 0.743 and Islamic bank governance 0.520. By looking at the AVE value, it can enter into other convergent validity criteria. And all constructs are also proven to be reliable because the value of Composite Reliability is more than 0.7 , sharia compliance is 0.962 , customer trust is 0.953 , 
Islamic bank governance is 0.948 and the Cronbach Alpha value is sharia compliance 0.954 , customer trust 0.942 , Islamic bank governance 0.942 is more than 0.70 . This means that each indicator can consistently measure its construct. Indicators and constructs are also free from multicollinearity. If the VIF value is between 5-10 it can be said that the indicator is multicollinearity. From the table, it can be seen that all the VIF values of the indicators are below 5, so there is no indication of multicollinearity, but there is a multicollinearity between the $\mathrm{K} 02$ indicator of 7,573 and $\mathrm{K} 03$ of 7,033 due to similar questions.

The goodness of the model can be seen from the R2 value and the Q2 value. In the study, it was found that the value of R2: 0.659 for the customer confidence construct means that sharia governance and compliance can explain the variance of customer trust by $66 \%$ and $34 \%$ of customer trust is explained by other factors. So, it can be interpreted that this value indicates that the model has a good ability to explain customer trust.

Furthermore, the Predicted Capacity (Q2) or known as the StoneGeisser's test. This test is performed to determine predictive ability with a blindfolding procedure. The values obtained were compared with standard values as follows:> 0.02 (predictive capacity: minor),> 0.15 (predictive capacity: medium) and $>0.35$ (predictive capacity: large). This test can only be performed for endogenous extracts with a reflective indicator. From the test results The Q2 value for the predictive capacity of the model, it is obtained that the predictive capacity for the customer confidence construct is $>0.35$, this means that the model has a strong capacity for prediction. The Q2 value of customer satisfaction is 0.466 , which means that the model has a strong predictive capacity.

\section{Conclusion}

Based on the research conducted by the author, the conclusion is that the governance variable has a positive effect on the level of customer confidence in Islamic banks in Bogor, but not significant. So that although the better the governance, it does not have a significant effect on the level of customer 
confidence in Islamic banks. On the other hand, sharia compliance has a very positive and significant effect on the level of customer confidence in Islamic banks. The better the sharia compliance, the higher the level of trust customers towards Islamic banks. Thus, in increasing customer confidence in Islamic banks, it is necessary to improve the governance of Islamic banks but prioritize improvements to sharia compliance.

\section{References}

Ahmed, H., \& Chapra, M. U. (2002). Corporate Governance in Islamic Financial Institution (Occasional Paper) (No. 93). The Islamic Research and Teaching Institute (IRTI).

Hermawan, D. (2005). Penelitian Bisnis Paradigma Kuantitatif. Jakarta: PT.Grasindo.

Khairandy, R., \& Malik, C. (2007). “Good Corporate Governance", Perkembangan Pemikiran dan Implementasinya di Indonesia dalam Perspektif Hukum. Yogyakarta: PT. Total Media.

Noman, A. M. (2003). Imperatives of Financial Innovations For Islamic Banks. International Journal of Islamic Financial Services, Vol. 3(5).

OJK. (2019). Statistik Perbankan Syariah. Jakarta: Otoritas Jasa Keuangan.

Rumadan, R., Askandar, N. S., \& Amin, M. (2018). Pengaruh Implementasi Syariah Governance Terhadap Loyalitas Nasabah. E-JRA: 39-50.

Sugiyono. (2011). Metodepenelitian Kuantitatif, Kualitatif dan $R \mathcal{E}$ D. Bandung: ALfabeta.

Wardayati, S. M. (2011). Implikasi shariah governance terhadap reputasi dan kepercayaan bank syariah. Walisongo: Jurnal Penelitian Sosial Keagamaan, Vol. 19(1), 1-24.

Yuraida, S., Kom, S., \& Keuangan, K. (2016). Pengaruh Shariah Governance Terhadap Kepercayaan Nasabah Bank Syariah dengan Reputasi Perbankan sebagai Variabel mediasi (Tesis). Yogyakarta: Pascasarjana UIN Sunan Kalijaga. 